\title{
AGRICULTURE PRODUCTIVITY IN SOLAPUR DISTRICT OF MAHARASHTRA: A GEOGRAPHICAL ANALYSIS
}

\author{
AWATE S.J. ${ }^{1}$ AND TODKARI G.U. ${ }^{2}$ \\ ${ }^{1}$ Dept. of Geography, Walchand College, Solapur, MS, India. \\ ${ }^{2}$ Geography Dept. Shri Sant Damaji College, Mangalwedha, Solapur, MS, India. \\ *Corresponding Author: Email- govindtodkari@gmail.com
}

Received: January 15, 2012; Accepted: March 06, 2012

\begin{abstract}
As the largest private enterprise in India, agriculture contributes one forth of the national GDP. Agriculture has been and will continue to be the life line of India economy. However, agriculture productivity and development differ very much from region to region, which needs a detail investigation. The temperature and pedagogical conditions are favorable for growing valuable crops like jawar, sugarcane, oil seeds, bajara, wheat, etc. By contrast, very low level of agriculture productivity is confined to the tahsils belonging to drought prone areas having irregular rainfall, rugged topography and poor irrigation facilities. Inadequacy of water is main hurdle in agriculture productivity. For the present investigation tahsilwise secondary data has been collected from socio-economic review and District Statistical Abstract. The data collected has been processed and method of yield co-efficient method has been employed to find out the levels agriculture productivity. The result are shown in tabular and from and are also depicted by choropleth method on map. Hence, in present paper an attempt has been made to assess the regional disparities in levels of agriculture productivity in Solapur District of Maharashtra.
\end{abstract}

Key words- agriculture productivity, yield co-efficient, Technological factors, wide variation, sustainability.

Citation: Awate S.J. and Todkari G.U. (2012) Agriculture productivity in Solapur District of Maharashtra: A Geographical Analysis. International Journal of Agriculture Sciences, ISSN: 0975-3710 \& E-ISSN: 0975-9107, Volume 4, Issue 2, pp-186-189.

Copyright: Copyright@2012 Awate S.J. and Todkari G.U. This is an open-access article distributed under the terms of the Creative Commons Attribution License, which permits unrestricted use, distribution, and reproduction in any medium, provided the original author and source are credited.

\section{Introduction -}

Agriculture has been and will continue to be the lifeline of Indian economy. The progress made by agriculture in the last four decades one of the biggest success stories of free India. Agriculture and allied activities constitute the single largest contributor to the gross domestic product. Agriculture is the means of livelihood of about two-third of the workforce in the country. This increase in agriculture product has been brought about by bringing additional area under cultivation, extension of irrigation facilities, the use of improved high variety of seeds, water management and better techniques evolved through agriculture research, pesticides and cropping practices. However, agriculture productivity differ very much from region to region in Solapur District which needs a detail investigation.

\section{Objectives-}

The present investigation aims to find out meaning of agriculture productivity, different methods of measurement agriculture produc- tivity and evaluation the major crop productivity and spatial variation in agriculture productivity in study region.

\section{Database and methodology}

Present study mostly relies on the secondary data collected through Agriculture Department, District statistical Department of Solapur and socio-economic abstract of Solapur district in $2009 / 10$. For the present investigation, District is selected as in general and tahsils in particular. Firstly, major crops productivity is measured and the productivity indices have been calculated on the basis of a statistical technique formulated by Jasbir Singh. The Figers and district maps are used for comparative study of spatial distribution. The yield index of each crop is calculated by the equation given below:

Yield of Crop $=\frac{\text { Yield of crop ' } a \text { ' in the areal unit } \mathrm{X} 100}{\text { Yield of crop 'a' in the region. }}$




\section{Study Area}

The present study deals with the geographical perspectives of the agriculture in Solapur district. The Solapur district is bounded by $17^{\circ} 05^{\prime}$ North latitudes to $18^{\circ} 32^{\prime}$ North latitudes and $74^{\circ} 42^{\prime}$ east to $76^{\circ} 15^{\prime}$ East longitudes. The total geographical area of Solapur district is $14895 \mathrm{~K} . \mathrm{m}^{2}$. divided into eleven tahsils.

Climate of the district is dry. The daily mean maximum temperature range between $30^{\circ} \mathrm{C}$ to $35^{\circ} \mathrm{C}$ and minimum temperature range between $18^{\circ} \mathrm{C}$ to $21^{\circ} \mathrm{C}$. The highest temperature is $47^{\circ} \mathrm{C}$ recorded in the month of May. The average annual rainfall is registered 510 $\mathrm{mm}$. The soil of the district essentially derived from the Deccan trap. The soil of the district can broadly classify into three groups shallow, medium and deep soil.

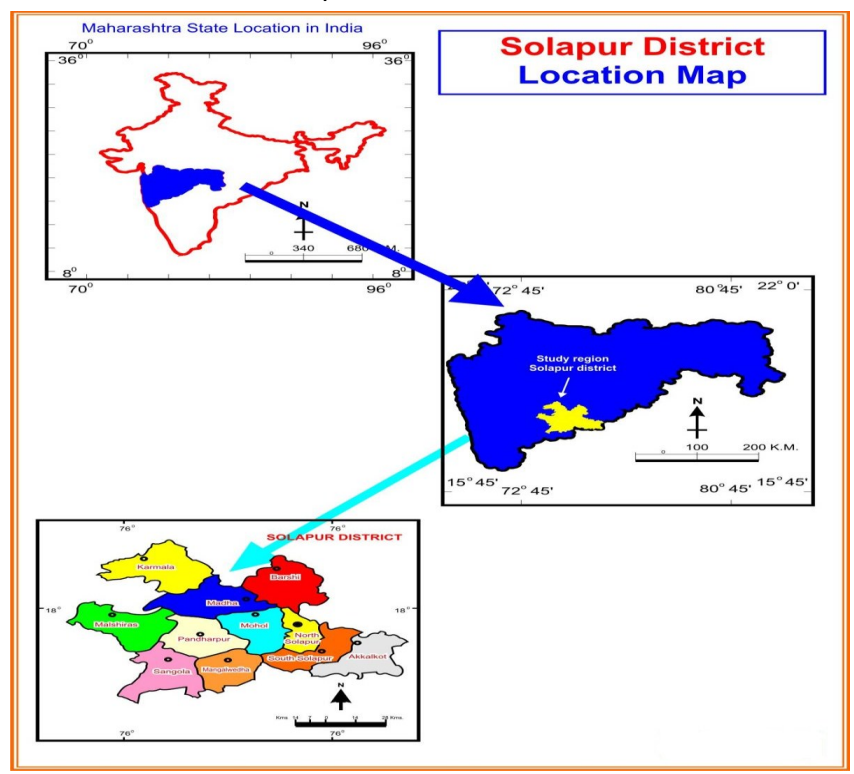

Fig. 1-

\section{Concept of Agriculture productivity-}

Agriculture productivity may be defined as the ratio of the index of total agriculture output to the index of total input used in farm production. In the conference of the Indian Economics (23rd) suggested by some economist that the yield per acre should be considered to indicate agriculture productivity. Pandit has stated that productivity is defined in economics as the output per unit of input or the getting some output from smaller input. He further suggested that increase in productivity is generally use of a more efficient use of all or some factors of production i.e. land, labour and capital.

Agriculture productivity on macro and micro level in the region closely influenced by various physical (physiography, soil, water, climate), socio-economic, political, technological and organizational factors. The traditional approaches of measurement of agriculture productivity does not take into consideration the social and environmental cost which are also helpful to increase the productivity of agriculture.

In recent decades geographers and economists have developed sophisticated tools and techniques to determine the agricultural productivity. Some of the techniques developed and used for measurement of agriculture productivity are given below

- Out per unit area

- Production per unit of farm level
- To asses agriculture production as grain equivalent (Buch, 1956)

- Input output ratio (Khusro 1964)

- Ranking co-efficient method (Kendal 1939, Stamp 1960, Shafi 1990)

- Carrying capacity of land in term of production (Stamp 1958)

- A system of four co-efficient a) productivity of co-efficient, b) ranking co-efficient, c) money value co-efficient, d) energy coefficient (Kendal 1939)

- Giving weight age to the ranking order of the output per unit area with the percentage share under each crop(Deshpade 1964, Bhatia 1967)

- Determing an index of productivity (Shafi 1972)

- Computing the crop yield and concentration indices ranking coefficient (Jasbir Singh 1976)

- To asses a agriculture productivity in term of money

- Assessing the net income in Rs per hectors of cropped (Jasbir Singh 1985)

\section{Productivity of principal crops}

Wheat, Jawar, Bajra, Maize, Tur, Gram, Sugarcane, Cotton and Groundnuts are the important crops of the Solapur District. Sugarcane and Jawar is accounting for more than 50 percent of the total cultivated area of the region. Jawar can be grown both a Rabi and Kharif crops in Solapur district. Wheat is more common in dry areas. Sugarcane is the principal crop of the region. It is a late arrival in the field of cash crops. Its cultivation is confined to the areas receiving adequate and timely irrigation.

The crop productivity changes have occurred in response to many technological developments during the last few decades. The adoption of seeds, fertilizers and irrigation has resulted into increase of farm production and diversifying the production pattern. The soil conservation has been an addition, for increasing the productivity. Thus, all these factors interact the changes in agricultural production.

Jawar Productivity- There are wide variations in the yield of Jawar in the region under study. The average productivity of the region as a whole is $449 \mathrm{Kg}$ per hectare. The tahsil wise yield ranges from $225.4 \mathrm{Kg}$. per hectare to $812.8 \mathrm{Kg}$ per hectare. In the region, the three tahsils have recorded a yield level of greater than $725 \mathrm{Kg}$. per hectare. The very high productivity is observed in Mangalvedha tahsil with an average productivity of $812.8 \mathrm{Kg}$ per hectare. The improved dry farming techniques assured supply of water, use of new strains of seeds, proper also of fertilizers, and modern methods in Jawar husbandry, all of them are responsible for higher production. The moderate level of productivity is noted in Karmala, Pandharpur, Mohol and South Solapur. At the other extreme, remaining all tahsils has low productivity with output per hectare of less than $425 \mathrm{Kg}$ per hectare.

Bajra Productivity-There are wide variations in the average level of productivity of bajra. The average productivity of bajra, in the region is $415 \mathrm{Kg}$ per hectare. In the region understudy the four tahsils have productivity above district average and seven tahsils have below average. The major parts of Solapur district i.e. Mohol and North Solapur have high level of bajra productivity. The 
moderate productivity is recorded in Barshi, Karmala, Malshiras, Sangola and Mangavedha tahsils. In Madha, Pandharpur, South Solapur and Akkalkot, the productivity is low. Recently new strains and the improvement in dry farming techniques have improved the productivity of bajra.

Table 1- Tahsilwise major crops productivity (2009/10)

\begin{tabular}{|c|c|c|c|c|c|}
\hline \multirow{2}{*}{$\begin{array}{l}\text { Sr. } \\
\text { No. }\end{array}$} & \multirow[t]{2}{*}{ Crops } & \multirow{2}{*}{$\begin{array}{l}\text { Yield/ } \\
\text { hectare } \\
\text { in } \mathrm{Kg} \text {. }\end{array}$} & \multicolumn{3}{|c|}{ Productivity tahsils } \\
\hline & & & High & Moderate & Low \\
\hline 1. & Jawar & 449 & Mangalvedha & $\begin{array}{l}\text { Karmala, } \\
\text { Pandharpur, } \\
\text { Mohol, } \\
\text { South Solapur }\end{array}$ & $\begin{array}{l}\text { Barshi, } \\
\text { North Solapur, } \\
\text { Malshiras, } \\
\text { Akkalkot, } \\
\text { Sangola, } \\
\text { Madha }\end{array}$ \\
\hline 2. & Bajra & 415 & $\begin{array}{l}\text { Mohol, } \\
\text { North Solapur }\end{array}$ & $\begin{array}{l}\text { Barshi, } \\
\text { Karmala, } \\
\text { Malshiras, } \\
\text { Sangola, } \\
\text { Mangavedha }\end{array}$ & $\begin{array}{l}\text { Madha, } \\
\text { Pandharpur, } \\
\text { South Solapur, } \\
\text { Akkalkot }\end{array}$ \\
\hline 3. & Wheat & 1100 & $\begin{array}{l}\text { Karmala, } \\
\text { Malshiras, } \\
\text { Pandharpur, } \\
\text { North Solapur }\end{array}$ & $\begin{array}{l}\text { Madha, } \\
\text { Mohol, } \\
\text { south Solapur }\end{array}$ & $\begin{array}{l}\text { Barshi, } \\
\text { Akkalkot, } \\
\text { Mangalvedha, } \\
\text { Sangola }\end{array}$ \\
\hline 4. & Tur & 387 & $\begin{array}{l}\text { North Solapur } \\
\text { South Solapur } \\
\text { Akkalkot }\end{array}$ & $\begin{array}{l}\text { Sangola, } \\
\text { Pandharpur, } \\
\text { Madha, Mohol }\end{array}$ & $\begin{array}{l}\text { Barshi, Karma- } \\
\text { la, Malshiras, } \\
\text { Mangalvedha }\end{array}$ \\
\hline 5. & Gram & 564 & $\begin{array}{l}\text { Barshi, } \\
\text { Karmala, } \\
\text { Malshiras, } \\
\text { South Solapur }\end{array}$ & $\begin{array}{l}\text { Sangola, } \\
\text { Pandharpur, } \\
\text { Madha, } \\
\text { Akkalkot }\end{array}$ & $\begin{array}{l}\text { North Solapur, } \\
\text { Mangalvedha, } \\
\text { Mohol, }\end{array}$ \\
\hline 6. & $\begin{array}{l}\text { Groun } \\
\text { dnut }\end{array}$ & 932 & South Solapur & $\begin{array}{l}\text { Barshi, } \\
\text { Karmala, } \\
\text { Malshiras } \\
\text { North Solapur, } \\
\text { Mangalvedha, } \\
\text { Mohol, } \\
\text { Sangola, } \\
\text { Pandharpur, } \\
\text { Madha }\end{array}$ & Akkalkot \\
\hline
\end{tabular}

Source- Complied by Author

Wheat productivity-The average productivity of wheat in the region is $1100 \mathrm{Kg}$. per hectare. There are only four tahsils which have a yield above $1500 \mathrm{Kg}$ per hectare. These four tahsils are namely Karmala, Malshiras, Pandharpur and North Solapur; all together make a major contribution to wheat output in the region. The moderate production of wheat is observed in Madha, Mohol, and south Solapur tahsils and low production in Barshi, Akkalkot, Mangalwedha and Sangola tahsils with an average productivity of $1000 \mathrm{Kg}$ per hectare.

Tur Productivity- Tur is a more important food grain of the region. The average productivity of the region is $387 \mathrm{Kg}$ per hectare. There are three tahsils namely, North Solapur, South Solapur, and Akkalkot, which have recorded productivity level higher than $500 \mathrm{Kg}$ per hectare. At the extreme, the four tahsils namely Barshi, Karmala, Malshiras and Mangalwedha which have productivity levels less than $250 \mathrm{Kg}$ per

hectare. Sangola, Pandharpur, Madha, Mohol tahsils have productivity ranging between 250 to $500 \mathrm{Kg}$. per hectare. The levels of tur productivity are very high in those parts of the district where tur concentration is significant. Tur is used by the people in daily diet as a pulse and hence, it is grown by the people in sizable area of the Solapur District.

Gram Productivity- Gram is known as (HARBARA) in rural areas. The average productivity of region is $564 \mathrm{Kg}$ per hectare. There are four tahsils namely Barshi, Karmala, Malshiras and South Solapur which have productivity, levels higher than $500 \mathrm{Kg}$ per hectare. There are three tahsils which have productivity levels, less than $250 \mathrm{Kg}$ per hectare. Low productivity occurs in North Solapur, Mangalvedha and Mohol, where local factors such as poor soils, relief and low intensity of irrigation directly affect the level of gram production. Elsewhere, the level of gram production ranges from 250 to $500 \mathrm{Kg}$ per hectare.

Groundnut productivity- Groundnut is the important oilseed crop of the region and its area of concentration is in southern part of South Solapur tahsil. The average productivity of region is $932 \mathrm{Kg}$ per hectare. It recorded high productivity with an average productivity of $653 \mathrm{Kg}$ per hectare while low productivity is in Akkalkot tahsil with an average productivity of 269 kilogram per hectare. Elsewhere, the levels of production are moderate due to agronomic limitation and the competition with grain crop.

\section{Measurement of Productivity by Yield Index Method}

The regional imbalance in agricultural productivity of Solapur district is measured by using index method. While applying this method, the seven crops grown in most of the tahsils are selected.

Areas of high productivity- It is mainly confined to the central and eastern part of district excluding south Solapur tahsil. Thus the tahsils of Mohol, Karmala and North Solapur recorded high productivity.

Areas of moderate productivity- This category of productivity is mainly observed in western part of Solapur district except Karmala. The rainfall is low in sangola tahsil. Irrigation facilities are not more developed. The average yield of crop is low. Kharif crops are dependent on monsoon and Rabi crops are grown only where water is available for irrigation.

Areas of low productivity- In the central part of Solapur district low production is recorded. This part consists of Madha, Pandharpur, Malgalvedha and Akkalkot tahsils. Hence, the yield of crops is very low. The irrigation facilities are not developed. Agricultural implements are old and traditional. Rainfall is uncertain, thus, the combined effect of all these factors leads to the low agricultural productivity.

Table 2- level of Agriculture Productivity

\begin{tabular}{|c|c|c|c|c|c|}
\hline $\begin{array}{l}\text { Sr. } \\
\text { no. }\end{array}$ & $\begin{array}{l}\text { Agriculture } \\
\text { productivity }\end{array}$ & $\begin{array}{l}\text { Co-efficient } \\
\text { value }\end{array}$ & $\begin{array}{l}\text { Share of agri. } \\
\text { Productivity } \\
\text { region }(\%)\end{array}$ & $\begin{array}{l}\text { No of } \\
\text { tahsils }\end{array}$ & Tahsils name \\
\hline 1 & High & Above 115 & 25.20 & 3 & $\begin{array}{l}\text { Karmala, } \\
\text { N. Solapur, } \\
\text { Mohol }\end{array}$ \\
\hline 2 & Moderate & $90-115$ & 38.60 & 4 & $\begin{array}{l}\text { Malshirash, } \\
\text { Sangola, } \\
\text { Barshi, } \\
\text { S. Solapur }\end{array}$ \\
\hline 3 & Low & Below 90 & 36.19 & 4 & $\begin{array}{l}\text { Mangalwedha, } \\
\text { Madha, } \\
\text { Pandharpur, } \\
\text { Akkalkot }\end{array}$ \\
\hline
\end{tabular}

Source- complied by Authors. 


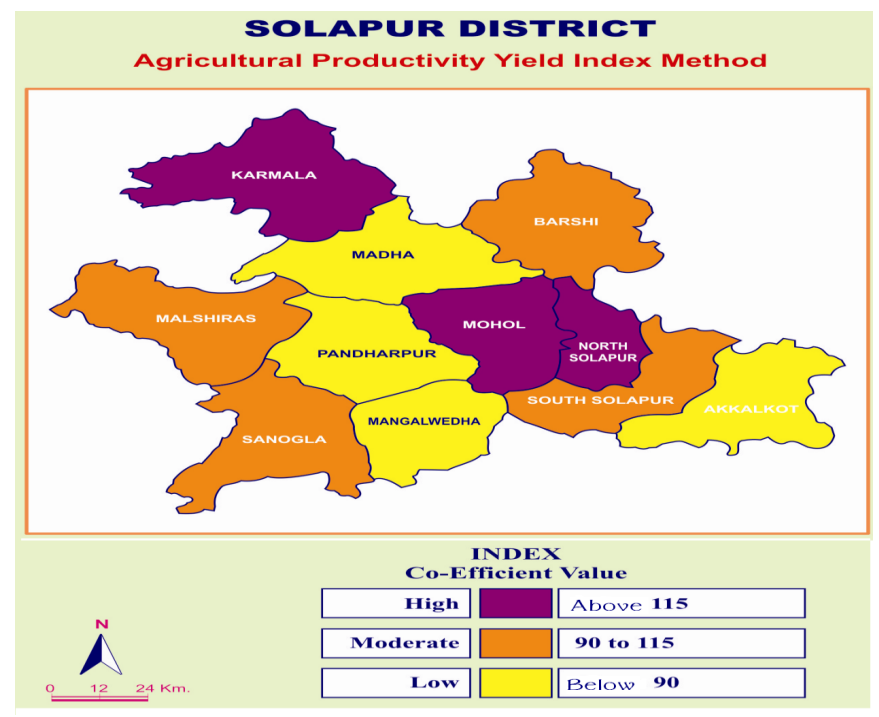

Fig. 2-

\section{Concluding Remarks}

The analysis reveals that there are great variation in level of agriculture productivity throughout the study region. Only 25.20 percent area of the study region is high productivity region, whereas 36 percent area of the study region is belong to low level of agriculture productivity. Relatively high level of productivity is observed in Karmala, N. Solapur and Mohol tahsils. The low level of productivity is confined to 4 tahsils which falls mostly in drought prone areas having inadequate, irregular and insufficient rainfall. And another group of tahsils belongs to high use of irrigation water where one crop (sugercane) is continuous cultivated.

The foresaid analysis clearly indicates that there are rare variation in level of agriculture productivity in the region. It needs to be taken care of while formulating development of productivity policies. The tahsils with low level of agriculture productivity should be given top priority so that they may come up at par with high productivity areas and the concept of social justice may be fulfilled.

\section{References -}

[1] Bharadwaj O.P. (1964) The national Geographical Journal of India., 10(2).

[2] Majid Hussain (2004) Agriculture Geography.

[3] Mohammad Shafi (2006) Agriculture Geography.

[4] Noor Mohammad (1992) New dimensions in Agricultural Geography. 8(4).

[5] Patil N.D. (1981) Improved crop production technology for drought prone areas of Maharashtra.

[6] Siddiqui A.R. and Jat B.C. (2009) The Deccan geographer, 48 (2).

[7] Varsha Vaidya and Date V.S. (1992) Transaction of the institute of Indian geographers, 14(2).

[8] Vishwakarma D.D. (2009) The Deccan geographer, 48(2). 